\title{
Linguistic Disfluency Induced by Nonword and Sentence Repetition Tasks in Preschool Children with and without Vocabulary Delay
}

\author{
Yoonhee Yang, Hyun Sub Sim, Dongsun Yim \\ Department of Communication Disorders, Ewha Womans University, Seoul, Korea
}

Correspondence: Hyun Sub Sim, PhD Department of Communication Disorders, Ewha Womans University, 52 Ewhayeodae-gil, Seodamun-gu, Seoul 03760, Korea Tel: $+82-2-3277-2120$

Fax: +82-2-3277-2122

E-mail: simhs@ewha.ac.kr

Received: July 5, 2017

Revised: August 22, 2017

Accepted: September 6, 2017
Objectives: All children demonstrate subtle linguistic disfluencies; children with vocabulary delay (VD), regardless of the presence of speech disorders, tend to produce disfluencies when phonological (linguistic) demands exceed their capacities. The current study examined whether the subtypes of linguistic disfluencies induced by nonword repetition (NWR) and sentence repetition (SR) tasks can discriminate between children with VD those without VD. Methods: Seventeen children with VD between the ages of 5 to 6 and 18 agematched children with normal language (NL) participated in this study. Participants' performance was assessed with NWR and SR, which impose a load on phonological memory. We analyzed speech samples collected during two repetition tasks. Repeated measured ANOVA, Pearson product-moment correlation, and stepwise multiple regression were used for data analysis. Results: Significant differences were found according to group and disfluency subtype. In the VD group, expressive vocabulary scores only correlated with R2 (Repetition2) in SR; this did not significantly correlate with any of the linguistic subtypes in the NL group. R2 in SR in the VD group showed significant predictive power for expressive vocabulary scores. Conclusion: These results demonstrate that linguistic disfluencies are more common in VD than NL groups. The VD children produced more disfluencies, especially with sentence level stimuli; these stimuli may place a greater phonological processing load on the children to recall content. Such a phonological (linguistic) load may negatively influence their speech planning and production.

Keywords: Linguistic disfluency, Preschool language delay, Phonological memory load, Nonword repetition, Sentence repetition
학령전기 아동들의 언어 이해 및 표현능력은 연령이 증가함에 따라 점차 정교화된다. 만 3 세에는 이해하지 못했던 문장을 4 세 전 반부터는 어순 단서를 활용하여 문장을 이해하게 되고, 만 4 세 후 반에 이르게 되면서부터 문법에 근거한 조사 단서를 사용하여 문 장을 이해하고 표현할 수 있게 된다(Jong \& Rhee, 1999; Jung, 1994). 특히, 학령전기 언어능력의 가장 기초적인 측정치인 어휘능력이 발 달됨에 따라, 아동이 이해하고 표현할 수 있는 어휘가 증가하게 되 며 전반적인 언어능력도 발달한다고 보았다(Pae, Rice, \& Oetting, 1999). 아동의 연령이 증가함에 따라 학령전기에 습득된 다양한 어
휘를 기초로 하여 복잡한 구문구조로 이루어진 발화산출이 가능 하게 되며, 의미가 부여된 어휘에 문법적 요소가 부가되어 아동의 언어능력은 보다 정교화된다.

그러나, 일반 아동들일지라도 말 또는 언어장애 아동들처럼 음 운 오류 또는 비유창성을 자주 보이며(Adams, 1977; Stoel-Gammon \& Dunn, 1985), 학령전기 아동들의 언어능력은 급격한 발달 과정 속에 놓여있기 때문에 언어발달지연의 유무에 상관없이 미완 성 언어의 표현이 아동발화에서 쉽게 발견된다(Shapiro, 1999). 이 와 같은 학령전기 아동에서 관찰되는 비유창성의 보편적 출현경향 
Yoonhee Yang, et al. • Linguistic Disfluency Induced by Nonword and Sentence Repetition Task

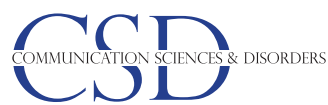

에 근거하여 학령 전 시기 언어학적 비유창성 문제를 ‘장애’로 보기 보다는, 말을 산출하기 전 자신이 표현하고자 하는 내용을 말에 담 아내기 위한 계획단계에서 오류를 미리 탐지하고 수정하기 위한 정 상적인 반응으로 간주하기도 한다(Lee \& Sim, 2003; Postma, Kolk, \& Povel, 1990). 이러한 언어학적 비유창성을 말 산출 시 어떤 방향 으로 가야 할지 길을 헤매게 된다는 뜻에서 '미로(maze)'라는 용어 로 표현하기도 한다(Loban, 1976). 언어학적 비유창성은 ADHD 및 $\mathrm{SLI}$ 를 포함한 다양한 의사소통장애 아동에게서 높은 빈도로 나타 나며, 언어산출 기저의 인지적 처리과정을 반영하고, 언어산출의 계획과 구성 및 실행상의 어려움을 나타내는 하나의 표지로 볼 수 있다(Dollaghan \& Campbell, 1992; Guo, Tomblin, \& Samelson, 2008; Lim \& Hwang, 2009; Navarro-Ruiz \& Rallo-Fabra, 2001; Redmond, 2004). 언어학적 비유창성의 하위유형의 분류체계는 반 복(repetition), 수정(revision), 간투사(interjection), 비운율적 발성 (disrhythmic phonation) 등과 같은 요소들을 포함한다(Fiestas, Bedore, Peña, \& Nagy, 2005). Loban (1976)은 언어장애 집단이 일 반아동 집단에 비해 언어학적 비유창성의 빈도가 더 많이 나타나 는 것으로 보고하였다. 뿐만 아니라 여러 선행연구들도 언어학적 비유창성과 언어능력 간 부적 상관관계가 있음을 지적하였다(Dollaghan \& Campbell, 1992; Guo et al., 2008; Navarro-Ruiz \& RalloFabra, 2001; Redmond, 2004).

Hall, McGregor와 Oleson (2017)은 언어능력 중에서도 특히 어 휘-의미적 지식의 부족이 언어장애 집단의 비유창성에 기여하는지 살펴본 결과, 언어장애 집단은 일반 집단과 비교하여 덜 유창함을 보여주었다. Westby (1979)의 연구도 어휘발달지연을 보이는 아동 들이 정상 어휘발달을 보이는 아동에 비해 더 높은 비유창성 빈도 를 보였다고 보고하였다. 그러므로 언어 또는 어휘발달지연 아동의 언어학적 비유창성은 음운, 의미, 구문과 같은 언어적 지표와 함께 언어능력의 결함을 암시하거나, 장애유무를 설명해주는 요인으로 설정될 수 있다. 이와 같은 선행연구결과들을 토대로 언어능력과 비유창성과 관련 있다는 주장이 제기되었으며, 비유창성은 언어산 출을 위한 내적 프로그래밍 단계와 말 산출 계획단계에서 발생되는 문제와 관련이 있음이 제기되었다.

이처럼 언어학적 요인이 비유창성과 연관되어 있다는 것이 수많 은 선행연구들을 통해 입증되어왔으나, 구체적으로 언어학적 비유 창성의 어떤 특성이 언어능력 또는 어휘발달지연에 기여하는지는 명확하게 밝혀지지 않았다. 즉, 선행연구에서 비유창성은 언어학적 수정처리와 밀접한 관련이 있는데(Postma, 1991; Postma \& Kolk, 1992), 화자의 말소리 오류가 입 밖으로 산출되기 전 음운 계획에서 의 오류가 탐지되면, 말소리 오류에 대한 수정을 내적으로 시도하
는 과정에서 비유창성이 발생할 수 있다고 본다(Postma \& Kolk, 1993). 또한, 언어발달에 지연이 있거나장애가 있는 아동의 경우 언 어 및 음운학적 취약성을 지니고 있으므로 음운 부호화 메커니즘 을 느리게 활성화시키는 경향이 있으며, 적절한 목표 음소 선택에 어려움을 보인다면 비유창성의 발생 확률이 높아질 수 있다. 따라 서 어휘발달지연 및 장애의 유무와는 상관없이 학령전기 아동들 에게서 비유창성은 공통적으로 흔하게 나타나지만, 언어 및 음운 학적 부담이 높은 과제를 통해 어휘발달지연 및 장애 아동들이 음 운적으로 복잡한 음절, 단어, 문장 등을 산출할 때 과연 비유창성 빈도가 증가하는가를 검증하는 시도가 요구된다(Melnick \& Conture, 2000). 이러한 시도들은 '요구-용량모델(Demands and Capacities Model)'에 의해 뒷받침될 수 있다(Adams, 1990; Melnick \& Conture, 2000; Starkweather, 1987).

'요구-용량모델'의 가설에 의하면, 비유창성은 개인 내적 또는 외 적으로 부과되는 의사소통의 요구가 아동의 언어적, 운동적, 정서 적, 인지적인 용량을 넘어서기 때문에 발생한다고 본다(Adams, 1990; Starkweather \& Gottwald, 1990). 즉, 아동에게 자극이 낯설 거나, 자극의 길이가 길거나, 또는 구문적으로 복잡할 때 아동에게 요구되는 자원의 총량이 증가하므로 말 산출에 대한 부담 또한 증 대될 수 있다는 것이다(Sung \& Sim, 2002; Yaruss, 1999). Logan과 Conture (1995) 역시 다양한 언어학적 영역 내에서 어느 한 영역이 라도 요구를 증가시키면 관련 과제의 수행 시 정확도가 감소된다고 보았다. 이러한 관점에서 보면, 비유창성이 증가되는 것은 언어학적 영역 내외적인 교환효과가 발생할 수 있어 한 영역에서의 복잡성 증 가로 인해 다른 영역의 정확도가 감소하기 때문이라고 볼 수 있다. 예를 들면, 음운 복잡성 및 난이도가 증가되면 유창성에 영향을 주 어 비유창성이 증가될 수 있다(Crystal, 1987; Masterson \& Kamhi, 1992).

비유창성을 분석하기 위한 연구방법은 크게 2가지로 나누어질 수 있다. 첫 번째 방법은, 자연스러운 상황에서 발생하는 비유창성 을 관찰하는 것이고(Clark \& Tree, 2002), 두 번째 방법은, '요구-용 량모델'을 반영한 것으로 아동의 능력을 넘어서는 부담(load)을 부 과하여 비유창성을 유도하는 실험과제를 사용하는 것이다(Oomen \& Postma, 2001). 말 산출에 뚜렷한 어려움이 없는 언어 및 어휘발 달지연 및 또래 일반 아동은 모두 자연스러운 상황에서는 유창한 발화를 산출하지만, 비유창성을 유도하는 음운적(언어학적) 부담 이 주어지면, 말 산출의 계획단계에서부터 언어 및 어휘발달지연 아동들은 또래 일반 아동에 비해 상대적으로 비효율적인 과정을 거치게 될 수 있다. 즉, 비유창성 유도 과제 수행을 통해 어휘발달지 연 아동의 어휘 회상, 구문의 음운 및 의미적 정보들을 사용하는 
데 겪게 되는 어려움들이 산출된 발화에 드러날 수 있다. 예를 들 어, 회피하기가 어려운 따라말하기 및 이야기 다시 말하기 활동을 통해 목표 자극을 음운적으로 복잡한 단어나 문장으로 구성하고 즉각 산출하도록 하여, 어휘발달지연 아동들이 부과된 과제에서의 요구가 본인의 용량을 넘어설 때 어떤 반응 및 전략들이 사용되는 가를 확인해볼수 있다(Conture, 2001). 이 방법을 통해서는 일상생 활에서의 자연스러운 발화를 살펴볼 수는 없으나, 자발화 분석에 서 통제할 수 없는 다양한 외부변인을 통제할 수 있고, 연구자가 보 고자 하는 과제 유형 및 음절 수, 구문 난이도를 조작하여 살펴볼 수 있다는 장점을 지닌다.

Ratner와 Shi (1987)는 만 3-6세의 아동들이 비유창성 증상의 유무와는 상관없이 비유창성 빈도가 발화 길이보다는 통사적 복 잡성과 상관관계가 있음을 확인하였으나, Richels, Buhr, Conture 와 Ntourou (2010)는 평균연령 만 4세의 아동들을 대상으로 문장 의 길이가 증가할수록 비유창성도 증가할 수 있다고 보았다. 반면, 만 3-7세의 연령대에서 통사적 복잡성이 비유창성 빈도에 미미한 영향을 준다고 보고되기도 하였다(Gordon, 1991). 국내에서도 관 련 연구가 진행되었는데 만 3-5세의 유창성장애 아동에게 문장모 방과제를 실시하였을 때 발화길이 및 통사적 복잡성 모두 비유창 성의 빈도를 유의하게 증가시킨 것으로 보고되었다(Sung \& Sim, 2002). 이처럼 학령전기 및 학령기의 아동들의 언어학적 비유창성 과 관련된 국내외 연구결과들은 비일관적이다.

한편, 언어 또는 어휘발달지연 아동들의 발화 내에서 높은 빈도의 비유창성이 보고되고, 유창성장애 아동들에게서도 미묘한 언어 결함들이 나타나 언어능력과 말 유창 간에 긴밀한 관계가 있음이 선행연구들을 통해 보고되었다(Hall, Yamashita, \& Aram, 1993; Ryan, 1992). Hall 등(1993)의 연구에서는 학령전 발달적 언어장애 아동 60 명을 대상으로 언어샘플을 통해 비유창성 빈도를 분석하 였을 때, 언어장애가 있는 아동들에게서 더 많은 비유창성 빈도가 나타났으며, 이러한 비유창성은 언어적 측면의 어휘 및 구문적 발 달과 말 산출 요구 간의 불일치로부터 발생한다고 제안하였다. 또 한, 일부 연구들은 유창성장애 아동들이 언어능력에 상대적으로 제한점을 보인다는 것을 입증하였는데, 이러한 연구를 통해 유창 성장애 아동들이 미묘한 언어 결함을 보인다는 것을 확인하였다. Ryan (1992)은 표준화 언어검사도구를 활용하여 학령전기의 유창 성장애 아동 20 명, 일반 아동 20 명의 조음 및 전반적인 언어발달능 력을 측정하였다. 그 결과, 조음능력에서는 집단 간 차이가 나타나 지 않았으나, 전반적인 언어발달검사를 실시한 결과 유창성장애 아 동들은 일반 아동에 비해 유의하게 낮은 점수를 받았다. 이러한 선 행연구들을 통해 어린 학령전기 아동들의 언어능력과 말 유창성
간의 상호적 연결고리가 존재한다는 것을 확인해볼 수 있다. 이와 상반되는 연구로 일반 아동과 유창성장애 아동 간 언어능력에 차 이가 없거나 오히려 평균 이상의 표현언어능력을 가지고 있음을 입 증하는 연구 또한 존재하지만(Miles \& Ratner, 2001; Yairi \& Ambrose, 2005; Yairi, Ambrose, Paden, \& Throneburg, 1996), 비유창 성 발생 및 지속에 대해 발화길이와 같은 언어학적 요인이 영향을 미칠 수 있음이 보고되기도 하였다(Lee \& Sim, 2015).

지금까지 살펴본 바와 같이, 언어장애 유무와는 상관없이 모든 아동들에게서 언어학적 비유창성을 보임에도 불구하고(Shapiro, 1999), 언어장애 아동은 일반 아동에 비해 더 많은 언어학적 비유 창성을 산출하는 경향성이 있는 것 같다(Hall et al., 1993; Postma \& Kolk, 1993; Redmond, 2004). 또한 이들의 언어적 어려움은 자연 스러운 일상생활 속 발화에서 뚜렷한 말 장애는 없는 것으로 보고 된 언어발달지연 및 언어장애 아동일지라도 언어학적 요소인 음운 적 부담(load)이 증가함에 따라 언어학적 비유창성이 말 수준 (speech level)에서 증가할 수 있다는 가능성을 선행연구에서 제기 하였다(Nippold, 2002). 특히 연령이 증가할수록 아동의 발화에서 언어학적 비유창성의 비율은 감소하지만 수정(revision)의 상대적 인 비율은 오히려 증가하기도 했는데, 이는 높은 연령의 아동일수 록 자신의 말을 점검하는 능력이 향상되므로 자신이 의도한 언어 의 내용과 형식에 맞도록 보다 정교하게 말하고자 하기 때문인 것 으로 설명된다(Lim \& Hwang, 2009). 또한, 후기 아동기에는 시간 벌기를 위한 책략으로 사용되는 간투사 등의 언어학적 비유창성은 상대적으로 감소하고, 수정의 빈도가 증가한 것은 문법이 발달하 는 시기에 자신의 발화에 대한 점검능력이 증가하고 구문 형식을 정교화하고자 하는 의도가 반영된 것으로 보았다(Hall \& Burgess, 2000). 그러나, 초기 아동기 및 학령전기의 어휘발달지연 아동과 또 래 일반 아동의 말 수준에서의 특성을 살펴본 연구는 드문 것으로 나타난다. 또한, 비유창성을 유도하는 음운기억 부담이 주어지는 비단어 및 문장 따라말하기 과제에서의 비유창성 빈도가 어휘력을 설명해줄 수 있는지를 알아보는 연구 또한 드물기 때문에 관련 연 구의 필요성이 제기된다.

따라서 본 연구에서는, 비단어 및 문장 따라말하기 상황에서 (1) 만 5-6세 어휘발달지연 아동이 또래 일반 아동에 비해 더 많은 언 어학적 비유창성이 나타나는지, (2) 비단어 및 문장 따라말하기 과 제에서의 비유창성과 표현 또는 수용어휘력 간 상관관계는 유의하 게 나타나는지, (3) 언어학적 비유창성이 어휘발달지연 아동의 어 휘력을 설명해줄 수 있는지 알아보고자 하였다.

이에 대한 본 연구의 핵심적인 연구질문은 다음과 같다.

1) 학령전기 아동의 언어학적 비유창성은 과제 및 언어학적 비유 
Yoonhee Yang, et al. • Linguistic Disfluency Induced by Nonword and Sentence Repetition Task

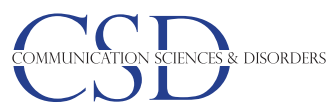

창성의 유형에 따라 집단 간(어휘발달지연 아동/일반 아동) 유의한 차이를 보이는가?

2) 학령전기 아동의 언어학적 비유창성은 표현 또는 수용어휘 점 수와 유의한 상관이 있는가?

3) 학령전기 어휘발달지연 아동들의 비단어 및 문장 따라말하기 과제 수행 시 나타난 언어학적 비유창성 특성이 이들의 부족한 어 휘력을 유의하게 설명할 수 있는가?

\section{연구방법}

\section{연구대상}

본 연구는 서울 및 수도권 지역에 거주하는 만 5-6세의 어휘발달 지연 아동 17 명, 그리고 생활연령을 일치시킨 일반 아동 18 명, 총 35 명을 대상으로 하였다. 본 연구의 어휘발달지연 및 일반 아동의 언 어검사는 연구자 본인이 직접 실시하였다.

본 연구에 참여한 어휘발달지연 아동은 (1) 아동의 주양육자 또 는 어린이집, 유치원 담임교사에 의해 인지 및 신체능력이 정상 범 주에 속하는 것으로 보고되고, (2) 카우프만 아동용 지능검사(Korean Kaufman Assessment Battery for Children, K-ABC; Moon \& Byun, 2003)의 비언어성 지능지수가 85점(-1 SD) 이상이며, (3) 수 용 및 표현어휘력검사(Receptive and Expressive Vocabulary Test, REVT; Kim, Hong, Kim, Jang \& Lee, 2009) 결과 수용 및 표현어휘 력점수 모두 자신의 생활연령 기준에서 -2 SD 미만이면서, (4) 정서, 행동, 감각(시각 및 청각), 사회적 상호작용 등의 문제가 없고, 기타 신경학적 결함의 이력이 없고, (5) 일상생활 속에서 뚜렷한 말 또는 유창성 문제는 없는 것으로 보고된 아동으로 선정하였다.

본 연구에 참여한 일반 아동은 (1) 아동의 주양육자 또는 초등학 교 및 유치원 담임교사에 의해 인지 및 신체능력이 정상 범주에 속 하는 것으로 보고되고, (2) 비언어성 지능지수가 85점(-1 SD) 이상 이며, (3) 수용 및 표현어휘력검사 결과 수용 및 표현어휘력점수가 모두 정상 범주(-1 SD 이상)에 속하며, (4) 정서, 행동, 감각(시각 및 청각), 사회적 상호작용 등의 문제가 없고, 기타 신경학적 결함의 이 력이 없고, (5) 일상생활 속에서 뚜렷한 말 또는 유창성 문제는 없는 것으로 보고된 아동으로 선정하였다.

어휘발달지연 아동 집단의 평균 생활연령은 $70.76(\mathrm{SD}=5.20)$ 개 월, 일반 아동 집단의 평균 생활연령은 $71.56(\mathrm{SD}=6.42)$ 개월이었 다. 어휘발달지연 집단의 동작성 지능 평균은 $104.71(\mathrm{SD}=10.68)$ 점 이고, 일반 아동 집단의 동작성 지능 평균은 $111.89(\mathrm{SD}=15.64)$ 점 이었다. 또한, 어휘발달지연 집단의 수용어휘력은 $50.53(\mathrm{SD}=8.88)$ 점, 일반 아동 집단의 수용어휘력은 $75.06(\mathrm{SD}=10.29)$ 점이고, 어휘
Table 1. Participants' characteristics

\begin{tabular}{lccc}
\hline Variable & VD $(\mathrm{N}=17)$ & $\mathrm{NL}(\mathrm{N}=18)$ & $t$ \\
\hline Age $(\mathrm{mo})$ & $70.76(5.20)$ & $71.56(6.42)$ & .399 \\
Nonverbal IQ & $104.71(10.68)$ & $111.89(15.64)$ & 1.577 \\
REVT-R & $50.53(8.88)$ & $75.06(10.29)$ & $7.530^{* *}$ \\
REVT-E & $58.76(9.02)$ & $81.17(11.33)$ & $6.449^{* *}$
\end{tabular}

Values are presented as mean (SD).

$\mathrm{VD}=$ children with vocabulary delay; $\mathrm{NL}=$ children with normal language; $\mathrm{REVT}=$ Receptive \& Expressive Vocabulary Test (Kim, Hong, Kim, Jang, \& Lee, 2010).

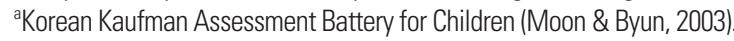
${ }^{* *} p<.001$.

발달지연 집단의 표현어휘력은 $58.76(\mathrm{SD}=9.02)$ 점, 일반 아동 집단 의 표현어휘력은 $81.17(\mathrm{SD}=11.33)$ 점이었다.

두 집단의 통제가 잘 이루어졌는지 확인하기 위해 독립표본 $t$-검 정을 실시한 결과, 연령 및 비언어성 지능에 통계적으로 유의한 차 이가 없었고 $(p>.05)$, 수용어휘력 $(t=7.530, p<.001)$ 및 표현 어휘력 $(t=6.449, p<.001)$ 에 대한 집단 간 차이가 통계적으로 유의하게 나 타났다. 두 집단 아동들의 생활연령, 비언어성 지능, 수용 및 표현어 휘력점수의 평균 및 표준편차는 Table 1에 제시하였다.

\section{연구도구}

본 연구에서는 학령전 어휘발달지연 아동 및 또래 일반 아동들 의 언어학적 비유창성을 확인하기 위해 아래와 같은 연구도구들을 사용하였다.

\section{비단어 따라말하기(Nonword Repetition Task)}

비단어 따라말하기 과제는 아동에게 음성 파일을 통해 비단어 를 제시하고, 아동이 제시되는 비단어를 즉시 따라 말하도록 고안 되었다. 본 연구의 과제는 한국어의 언어적 특성을 고려한 Lee, Yim 과 $\operatorname{Sim}$ (2012)의 비단어 따라말하기 과제를 사용하였다. 이 과제는 단어 유사성이 낮은 20 개의 비단어로 구성되어있으며, 이는 기존 어휘지식의 부족으로 인해 어휘발달지연 아동에게 발생할 수 있는 과제 수행상의 잠재적 불이익을 최소화하기 위함이다. 2음절부터 6 음절까지 음절의 길이는 점차 증가된다. 비단어 자극의 예는 2 음 절은 '퍼틱', 6음절은 '미기돋아캐바'와 같다.

검사는 소음이 없는 조용한 장소에서 아동과 평가자가 일대일로 착석하여 진행하였다. 검사자는 아동에게 제시되는 비단어 목표자 극 한 개씩을 미리 녹음된 음성파일로 헤드폰을 통해 듣게 하고 즉 시 반복하여 따라 말하도록 하였다. 비단어 음성파일은 한국인 성 인 여성의 음성으로 녹음되었으며, 2 음절 조건의 4 개, 3 음절 조건의 4 개, 4 음절 조건의 4 개, 5 음절 조건의 4 개, 6 음절 조건의 4 개, 총 20 
개가 길이 순으로 제시되었다. 본 검사가 실시되기 전, 평가자는 아 동에게 ‘앵무새 놀이’를 할 것이라고 과제를 소개하여, 음성과 똑같 이 따라 말해야 한다는 것을 아동이 이해할 수 있도록 평가자의 육 성을 들려주며 연습하였다. 또한, 아동이 과제 수행방법을 정확히 이해했는지 확인하기 위해 녹음된 음성파일로 충분한 연습문항을 실시하였다. 아동이 과제 수행방법을 이해하면 본 문항을 실시하였 다. 비단어 따라말하기 과제 목록은 Appendix 1에 제시하였다.

\section{문장 따라말하기(Sentence Repetition Task)}

문장 따라말하기 과제는 Ahn과 $\operatorname{Kim}$ (2000)의 연구에서 사용된 것으로, 총 35 개로 구성되어 있다. 문장의 길이는 3 어절과 5 어절, 구 문복잡성은 단문과 복문(접속, 내포)으로 구성되어 있다. 예를 들 어, 3 어절 문항은 ‘그림을 연필로 그려요.', 5 어절 단문은 '동생이 작 은 칫솔로 이빨을 닦아요.', 5어절 접속은 '친구가 목욕을 하고 머리 를 감아요.', 5어절 내포는 '친구가 잠을 자는 강아지를 깨워요.' 가 있다. 문장은 어절의 길이 및 구문 복잡성에 따라 3 어절 단문, 5 어절 단문, 5 어절 접속, 5 어절 내포 문항을 순차적으로 제시하였다.

평가자는 아동에게 들려주는 말을 똑같이 따라 말하는 과제의 수행방법에 대해 충분히 설명한 후 연습문항을 실시하고 아동이 과제에 대해 충분히 이해했다고 판단되면 본 문항을 실시하였다. 녹음파일을 통해 아동에게 문장을 들려준 후 평가자는 '일시 정지' 버튼을 눌러 아동이 반응할 수 있도록 하였으며, 아동은 문장을 즉 시 정확히 따라 말하는 방식으로 진행되었다. 연습문항에서 아동 이 정확히 따라 말하지 못했을 때는 기회를 추가적으로 제공할 수 있지만, 본 문항에서 아동이 정확히 따라 말하지 못할 경우 추가 기 회 없이 다음 문항으로 넘어가도록 하였다. 문장 따라말하기 과제 목록은 Appendix 2에 제시하였다.

\section{비유창성 빈도 분석}

본 연구에서는 비유창성 유형을 파라다이스 유창성검사(Paradise-Fluency Assessment II, P-FA II; Sim, Shin, \& Lee, 2010)에서 제시되는 유형 중 R1 (반복1), R2 (반복2), Rev (수정), I (간투사), $\mathrm{DP}$ (비운율적 발성)로 분류하였다. 즉, 비단어 및 문장 따라말하기 의 각 문항별 어절에 따라 R1 (반복1), R2 (반복2), Rev (수정), I (간 투사), DP (비운율적 발성), 총 5 가지에서 각각의 빈도를 기록하고 총점을 산출하였다(Lee, Park, Shin, \& Sim, 2009). 과제의 채점방 식은 각 과제에서 R1 (반복1), R2 (반복2), Rev (수정), I (간투사), $\mathrm{DP}$ (비운율적 발성)의 비유창성 출현 시 각각 1 점씩 부여하여 빈도 를 산출하였다. 같은 위치에서 두 가지 이상의 비유창성 유형을 보 였을 경우에도 모두 빈도에 포함되었다. 분석 기준과 예시를 Ap- pendix 3에 제시하였다.

\section{자료분석 및 결과처리}

본 연구의 모든 통계적 분석은 SPSS ver. 19 (SPSS Inc., Chicago, IL, USA)를 사용하였다. 집단 간 과제 및 비유창성 유형에 따라 언 어학적 비유창성 양상에 차이가 있는지 살펴보기 위해 반복측정 분산분석(repeated measured ANOVA)을 사용하였다. 이 분석에 서 피험자 간 요인은 두 집단(어휘발달지연 아동, 일반 아동), 피험 자 내 요인은 과제 유형(비단어 따라말하기, 문장 따라말하기) 2 가 지 및 언어학적 비유창성 유형(반복1, 반복2, 수정, 간투사, 비운율 적 발성) 5 가지로 하였다. 각 집단의 어휘력과 비유창성 간 상관관 계를 살펴보기 위해 Pearson의 적률상관계수(Pearson product monument correlation), 그리고 비단어 및 문장 따라말하기 과제 수행에서 나타난 언어학적 비유창성 빈도의 양상으로 어휘발달지 연을 통계적으로 유의하게 설명해줄 수 있는지 알아보기 위하여 단 계적 중다회귀분석(stepwise multiple regression)을 사용하였다.

\section{신뢰도}

비단어 따라말하기, 문장 따라말하기 과제 수행의 결과를 2 명의 언어병리학 박사과정생이 검사자가 되어 녹음파일을 듣고 전사하여 반복1 (R1), 반복2 (R2), 수정(Rev), 간투사(I), 비운율적 발성(DP), 총 5 가지 유형의 빈도를 측정하였다. 신뢰도는 검사자 간 일치한 항 목 수를 전체 항목 수로 나눈 다음 100 을 곱하여 산출하였다. 검사 자 간 신뢰도는 비단어 따라말하기의 경우 $98.3 \%$, 문장 따라말하 기의 경우 $98.8 \%$ 였다. 추후 명확하지 않은 부분은 논의를 거쳐 의 견을 하나로 수렴하였다.

\section{연구결과}

\section{집단 간(어휘발달지연 아동, 일반 아동) 과제 유형에 따른 언어학적 비유창성 빈도 비교}

과제유형(비단어, 문장) 및 비유창성 유형(반복1, 반복2, 수정, 간 투사, 비운율적 발성)에서 집단 간 수행 차이의 결과는 Figure 1, Table 2와같다.

어휘발달지연 아동 및 일반 아동 집단 간 과제 및 비유창성 유형 에 따른 과제 수행에 차이가 있는지 비교하기 위해 반복측정분산 분석을 실시하였다. 구형성 검정을 위해 살펴본 결과, Mauchly의 $\mathrm{W}$ 값이 과제 유형에서 1.000 , 언어학적 비유창성 유형에서 .674, 과 제 유형 $\times$ 언어학적 비유창성 유형에서 .404이었으므로 Huynh Feldt 엡실런으로 각각 $1.000, .952, .784$ 로 보완하였다. 집단 $\left(F_{(1,33)}=\right.$ 


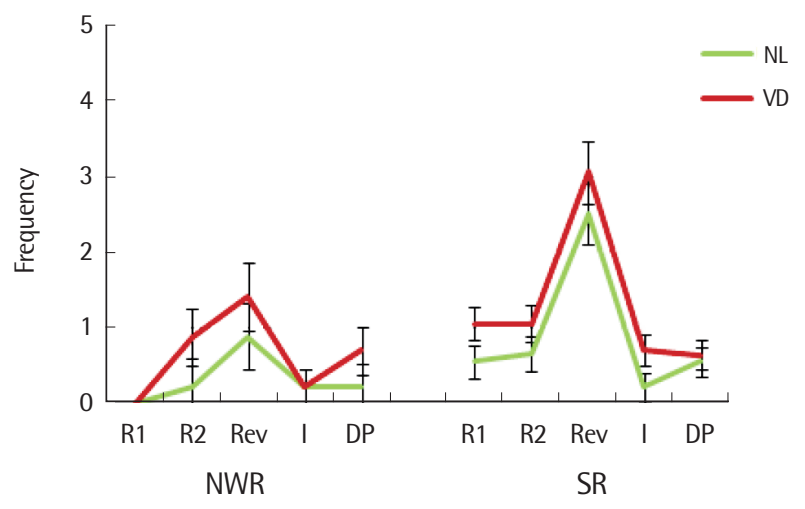

Figure 1. Linguistic disfluency characteristics by group, task and disfluency type. $\mathrm{NL}=$ children with normal language; $\mathrm{VD}=$ children with vocabulary delay; NWR= nonword repetition; $S R$ = sentence repetition; $R 1$ = repetition1; $R 2$ = repetition2; Rev= revision; I = interjection; $\mathrm{DP}=$ dysrhythmic phonation.
Table 2. Descriptive statistics of disfluency score by subgroups

\begin{tabular}{llcc}
\hline Variable & & VD (N=17) & NL (N=18) \\
\hline NWR & R1 & $0(.0)$ & $0(.0)$ \\
& R2 & $.88(2.06)$ & $.22(.94)$ \\
& Rev & $1.41(1.97)$ & $.89(1.71)$ \\
& I & $.24(.97)$ & $.22(.94)$ \\
SR & DP & $.71(1.57)$ & $.22(.94)$ \\
& R1 & $1.06(1.09)$ & $.56(.71)$ \\
& R2 & $1.06(1.03)$ & $.67(.91)$ \\
& Rev & $3.06(1.85)$ & $2.50(1.54)$ \\
& I & $.71(.99)$ & $.22(.65)$ \\
& DP & $.65(.70)$ & $.56(.86)$
\end{tabular}

Values are presented as mean (SD).

$\mathrm{VD}=$ children with vocabulary delay; $\mathrm{NL}=$ children with normal language; $\mathrm{NWR}=$ nonword repetition; SR=sentence repetition; $\mathrm{R} 1$ = repetition1; R2 = repetition2; Rev= revision; I = interjection; $\mathrm{DP}=$ dysrhythmic phonation.

Table 3. Correlation coefficients among REVT and linguistic disfluency subtypes in VD group

\begin{tabular}{|c|c|c|c|c|c|c|c|c|c|c|}
\hline Variable & NWR_R1 & NWR_R2 & NWR_Rev & NWR_I & NWR_DP & SR_R1 & SR_R2 & SR_Rev & SR_I & SR_DP \\
\hline REVT-R & - & .428 & .312 & .449 & -.028 & .003 & -.455 & .317 & -.003 & .443 \\
\hline REVT-E & - & -.072 & .161 & .092 & -.376 & .052 & $-.685^{*}$ & -.194 & -.290 & .391 \\
\hline
\end{tabular}

REVT = Receptive \& Expressive Vocabulary Test (Kim, Hong, Kim, Jang, \& Lee, 2010); VD=children with vocabulary delay; NWR= nonword repetition; SR= sentence repetition; $\mathrm{R} 1$ = repetition1; $\mathrm{R} 2$ = repetition2; Rev= revision; I= interjection; $\mathrm{DP}=$ dysrhythmic phonation. ${ }^{*} p<.01$.

$5.28, p<.05)$ 및 과제유형 $\left(F_{(1,33)}=24.599, p<.001\right)$, 비유창성 유형 $\left(F_{(1,33)}=25.749, p<.001\right)$ 의 주효과가 유의하였다. 즉, 일반 아동 집 단은 어휘발달지연 아동에 비해 비유창성 빈도가 유의하게 낮았으 며, 비단어 따라말하기에서의 비유창성 빈도와 비교하여 문장 따 라말하기에서의 비유창성 빈도는 유의하게 높게 나타났다. 5 가지 비유창성 유형의 주효과가 유의하게 나타남에 따라 Bonferroni 사 후비교분석을 실시한 결과, 수정(Rev)과 그 외 모든 요인(반복1, 반 복 2 , 간투사, 비운율적 발성)이 유의한 차이가 있는 것으로 나타났 다 $(p<.05)$.

과제유형 및 비유창성 유형에 따른 과제 수행에 유의한 차이가 있는지 살펴본 결과, 이차 상호작용이 유의하였다 $\left(F_{(4,132)}=4.547\right.$, $p$ <.01). 이에 따라 M-matrix를 사용하여 사후분석을 실시한 결과, 비단어 따라말하기에서는 수정과 반복 1 간 유의한 차이가 있었으 며, 문장 따라 말하기에서도 수정은 그 외 모든 요인(반복1, 반복2, 간투사, 비운율적 발성)과 유의한 차이가 있는 것으로 나타났다 $(p<.05)$.

그 외 집단 및 과제유형, 집단 및 비유창성 유형 간 이차상호작용 은 유의하지 않았으며, 집단과 과제유형 및 비유창성 유형에 대한 삼차상호작용 역시 유의하지 않았다 $(p>.05)$.

\section{각 집단(어휘발달지연 아동, 일반 아동)의 어휘력(REVT-R, REVT-E)과 언어학적 비유창성 간 상관관계}

일반 아동 집단에서 수용어휘력(REVT-R) 및 표현어휘력(REVT$\mathrm{E}$ )과 언어학적 비유창성 간 유의한 상관관계는 나타나지 않았다. 어휘발달지연 아동 집단에서도 수용어휘력(REVT-R)과 언어학적 비유창성 간 유의한 상관관계는 나타나지 않았으나, 표현어휘력 (REVT-E)과 'SR_R2 (문장 따라말하기_반복2)' 간 유의한 상관이 나타났다 $(r=-.685, p<.01)$. 이에 대한 결과는 Table 3과 같다.

\section{언어학적 비유창성 양상을 통한 어휘발달지연 예측요인 탐색}

본 연구의 비단어 및 문장 따라말하기 과제 수행에서 나타난 언 어학적 비유창성 빈도의 양상으로 어휘발달지연을 통계적으로 유 의하게 설명해줄 수 있는지 알아보기 위하여 단계적 중다회귀분석 (stepwise multiple regression)을 실시하였다. 어휘발달지연 집단을 케이스 지정하여 살펴보았으며, 독립변수는 비단어 및 문장 따라 말하기 각각의 R1 (반복1), R2 (반복2), Rev (수정), I (간투사), DP (비운율적 발성)으로 총 10 가지였고 종속변수는 표현어휘점수 및 수용어휘점수로 각각 나누어 살펴보았다. 중다회귀분석을 실시하 기 위해 다중공선성을 진단한 결과 Variance Inflation Factor (VIF) 
가 1.000 으로 다중공선성이 없는 것으로 판단되어 기본전제조건 을 만족함을 확인하였다.

그 결과, 어휘발달지연 아동 집단의 수용어휘력을 설명해주는 유의한 예측요인은 나타나지 않았으나, 표현어휘력을 유의하게 설 명해주는 예측인자로 'SR_R2 (문장 따라말하기_반복2)'가 나타났 다 $\left(F_{(1,16)}=13.294, p<.01, R^{2}=.47\right)$. 즉, 어휘발달지연 집단에서 'SR_ $\mathrm{R} 2$ '가 표현어휘력을 약 $47 \%$ 유의하게 예측해줄 수 있는 것으로 나 타났다.

\section{논의 및 결론}

본 연구는, (1) 학령 전 어휘발달지연 및 또래 일반 아동이 음운기 억 부담이 부과되는 비단어 및 문장 따라말하기 과제 수행 시 언어 학적 비유창성 양상은 집단 간 유의한 차이가 나타나는지, (2) 언어 학적 비유창성 빈도는 표현 또는 수용 어휘점수와 유의한 상관이 있는지, (3) 언어학적 비유창성이 어휘발달지연 아동의 어휘력을 유 의하게 예측할 수 있는지 알아보고자 하였다.

첫째, 어휘발달지연 아동은 또래 일반 아동보다 문장 따라말하 기 과제에서 더 많은 비유창성빈도를 보였으나, 비단어 따라말하기 과제에서는 집단 간 유의한 차이가 없었다. 이러한 연구결과는 자 극이 낮선 경우 말 산출에 대한 부담이 증가된다고 보았던 견해로 짧은 단어가 자극으로 사용되어 아동의 음운기억 용량을 넘어서 지 않는 경우는 적용되지 않을 수 있음을 시사한다(Conture, 2001). 반면, 상대적으로 자극의 길이가 길거나 구문적으로 복잡한 문장 수준의 과제일 경우 아동의 말 산출 시 미치는 영향력이 더욱 증대 되는 것으로 보인다(Richels et al., 2010; Sung \& Sim, 2002; Yaruss, 1999). 특히 어휘발달지연 아동들이 문장 따라말하기 과제에서 보 인 비유창성은 이 아동들이 지닌 어휘 및 구문능력과 청지각적 정 보를 정확히 저장하고 인출해야 하는 과제상의 요구와 능력 간의 불일치로 인해 일어나게 된다고 볼 수 있다. 즉, 어휘발달지연 아동 들에게 요구되는 문장 산출에 대한 부담이 일반 또래 아동들보다 상대적으로 더 크기 때문인 것으로 분석된다(Sung \& Sim, 2002; Yaruss, 1999).

비단어 및 문장 따라말하기 과제 모두에서 비유창성 유형에 따 라 빈도차이가 집단 간 유의하였으며, 모든 과제에서 '수정(revision)' 의 빈도가 가장 높게 나타났다. 선행연구에 따르면, 학령기로 접어 들수록 아동의 발화에서 언어학적 비유창성의 비율은 감소하지만, ‘수정'의 비율은 오히려 증가한다(Lim \& Hwang, 2009). 이는 아동 의 연령이 증가할수록 말 모니터링 능력이 향상되어 자신이 의도한 내용을 형식에 잘 담아 보다 정교하게 말하고자 하는 노력을 기울
이기 때문인 것으로 보인다. 그러나, 본 연구의 대상 아동은 학령기 아동들이 아닌 학령전기 아동들임에도 불구하고 비단어 및 문장 따라말하기 과제 수행 상황에서 ‘수정’이 일관적으로 높은 빈도로 나타났다. 이를 통해, 주어진 제시자극을 정확히 모방하는 것이 요 구되는 따라말하기 과제 수행 시 학령전기 아동에게서도 아동들 이 자신의 의도한 말을 점검하고자 하는 내적 모니터링이 활성화될 수 있음을확인할수 있다.

둘째, 비단어 및 문장 따라말하기에서 나타난 언어학적 비유창 성 유형과 표준화 언어검사를 통한 표현 또는 수용어휘점수와 유 의한 상관이 있는지 알아본 결과, 일반 아동 집단에서는 유의한 상 관관계가 나타나지 않았으나, 어휘발달지연 아동에게서 표현어휘 력(REVT-E)과 문장 따라말하기 수행 시의 R2 사이에 유의한 상관 관계가 있는 것으로 나타났다. 이는 언어에 결함이 있는 아동 집단 에게서 언어학적 비유창성과 언어능력의 부적 상관관계가 나타남 을 밝힌 선행연구들과 일치한다(Dollaghan \& Campbell, 1992; Guo et al., 2008; Navarro-Ruiz \& Rallo-Fabra, 2001; Redmond, 2004). 즉, 본 연구의 일반 아동 집단에서 언어학적 비유창성 하위 유형들은 표준화 언어검사 점수인 어휘점수와 상관이 없었지만, 어 휘발달지연 아동들의 언어학적 비유창성은 표현어휘력과 높은 부 적 상관관계가 확인되었다. 일반 아동 집단에서는 어휘집(lexicon) 에서 목표하고자 하는 어휘를 인출하고 표현하는 과정이 보다 효율 적이고 자동적으로 이루어지나, 언어 및 어휘발달지연 아동들은 일반 아동 집단에 비해 자신이 목표 어휘를 산출하기 위해 필요한 말을 모니터링하는 데에 지나치게 많은 노력을 쏟거나, 비효율적인 과정을 거칠 수 있으므로 비유창성이 발생할 수 있다(Postma \& Kolk, 1993). 특히 R2가 어휘발달지연 아동 집단의 표현어휘력과 유의한 상관관계가 있는 것으로 나타난 것은 주목해 볼만한 결과 이다. 정상적 비유창성으로 분류되는 반복1 (R1)과는 달리, R2는 P-FA II (Sim et al., 2010)의 기준으로 정상적인 비유창성이 아닌 '병 리적인 비유창성'으로 분류되는 하위유형으로, 음소, 음절부분, 음 절, 낱말부분, 일음절 낱말의 반복이 이에 속한다. 음운기억에 부담 이 제공되는 과제 수행 시 어휘발달지연 아동에게서 취약한 표현어 휘력과 병리적인 비유창성 간 유의한 상관관계가 나타난 것은 언어 능력과 말 유창성 간의 긴밀한 연결고리가 존재함을 시사한다(Hall et al., 1993; Ryan, 1992).

셋째, 비단어 및 문장 따라말하기 과제 수행 시 나타나는 언어학 적 비유창성이 어휘발달지연 아동의 어휘력을 설명해줄 수 있는지 를 분석한 결과, 문장 따라말하기 과제에서 나타난 'R2'가 표현어휘 력을 약 $47 \%$ 설명해줄 수 있는 것으로 나타났다. 설명력을 나타내 는 결정계수 $\left(R^{2}\right)$ 값의 기준은 분야마다 다를 수 있지만 사회과학 
또는 행동과학 연구에서는 .26 (26\%) 이상일 경우 그 값이 충분히 크다고 언급하고 있다(Cohen, 1988). 따라서 'R2'의 설명력은 충분 히 높다고 해석해볼 수 있다. 말 산출을 요구받지 않고도 점수 획득 이 가능한 수용어휘력에 비해, 직접 어휘집(lexicon)에 있는 어휘를 산출할 것이 요구되는 표현어휘력은 말 지표인 언어학적 비유창성 과 밀접하게 연결되어 있을 수 있다. 본 연구에서 언어학적 비유창 성인 'R2'의 어휘발달지연 아동의 표현어휘력에 대한 설명력이 $47 \%$ 에 이르는 만큼, 학령전기 아동들의 언어 및 말 유창성 간의 상 호적 연결고리는 더욱 견고히 드러난 것으로 보인다.

본 연구의 제한점은 연구대상을 전반적인 언어문제를 포괄하는 언어장애 아동이 아닌 어휘발달지연 아동으로 축소함으로써 연구 결과의 적용이 매우 한정적일 수 있다는 것이다. 그러나 본 연구를 통해 어휘발달지연 및 또래의 일반 아동들은 평소 자발화 상황에 서는 비유창성 요소에서 차이점이 거의 드러나지 않지만, 문장의 길이 및 구문구조의 복잡성과 같은 부담(load)이 증가하게 되면, 특 히 어휘발달지연 아동은 상대적으로 목표단어 및 문장의 산출을 위한 프로그래밍 시 또래 일반 아동에 비해 더 많은 노력이 요구될 수 있는 가능성을 확인하였다. 따라서 말 산출을 위한 충분한 시간 을 제공하거나, 용량을 넘어서는 요구를 피하기 위해 아동들에게 음운루프 사용을 원활하게 하기 위한 구어 리허설(verbal rehears$\mathrm{al)}$ 을 촉진시키고, 새롭게 들어오는 말을 관리하기 쉬운 정보의 단 위로 만드는 청킹(chunking) 기술을 사용할 수 있게 할 수 있다 (Montgomery, 2003). 그밖에, 말하기 상황에서 목표하는 단어 및 문장의 길이 및 복잡성의 부담을 스스로 최대한 줄여 산출하는 훈 련이 필요할 수 있다.

\section{REFERENCES}

Adams, M. R. (1977). A clinical strategy for differentiating the normally nonfluent child and the incipient stutterer. Journal of Fluency Disorders, 2, 141148.

Adams, M. R. (1990). The demands and capacities model I: theoretical elaborations. Journal of Fluency Disorders, 15, 135-141.

Ahn, J. S., \& Kim, Y. T. (2000). The effect of syntactic complexity on sentence repetition performance and intelligibility between specific language impairment and normal children. Korean Journal of Speech Sciences, 7, 249262.

Clark, H. H., \& Tree, J. E. F. (2002). Using uh and um in spontaneous speaking. Cognition, 84, 73-111.

Cohen, J. (1988). Statistical power analyses for the social sciences. Hillsdale,
NJ: Lawrence Erlbaum Associates.

Conture, E. G. (2001). Stuttering: its nature, diagnosis, and treatment. Boston, MA: Allyn \& Bacon.

Crystal, D. (1987). Towards a "bucket" theory of language disability: tacking account of interaction between linguistic levels. Clinical Linguistics and Phonetics, 1, 7-22.

Dollaghan, C. A., \& Campbell, T. F. (1992). A procedure for classifying disruptions in spontaneous language samples. Topics in Language Disorders, 12, 56-68.

Fiestas, C. F., Bedore, L. M., Peña, E. D., \& Nagy, V. J. (2005). Use of mazes in the narrative language samples of bilingual and monolingual 4-to 7-year old children. In J. Cohen et al. (Eds), ISB4: Proceedings of the 4th International Symposium on Bilingualism (pp. 730-740). Somerville, MA: Cascadilla Press.

Gordon, P. A. (1991). Language task effects: a comparison of stuttering and nonstuttering children. Journal of Fluency Disorders, 16, 275-287.

Guo, L. Y., Tomblin, J. B., \& Samelson, V. (2008). Speech disruptions in the narratives of English-speaking children with specific language impairment. Journal of Speech, Language, and Hearing Research, 51, 722-738.

Hall, J., McGregor, K. K., \& Oleson, J. (2017). Weaknesses in lexical-semantic knowledge among college students with specific learning disabilities: evidence from a semantic fluency task. Journal of Speech, Language, and Hearing Research, 60, 640-653.

Hall, N. E., \& Burgess, S. D. (2000). Exploring developmental changes in fluency as related to language acquisition: a case study. Journal of Fluency Disorders, $25,119-141$.

Hall, N. E., Yamashita, T. S., \& Aram, D. M. (1993). Relationship between language and fluency in children with developmental language disorders. Journal of Speech, Language, and Hearing Research, 36, 568-579.

Jong, E. H., \& Rhee, K. S. (1999). A study on the sentence comprehension strategies of Japanese-speaking children \& Korean-speaking children. Communication Disorders, 22, 77-94.

Jung, D. B. (1994). Language development teaching. Seoul: Korean Culture Book.

Kim, Y. T., Hong, G. H., Kim, K. H., Jang, H. S., \& Lee, J. Y. (2009). Receptive \& expressive vocabulary test (REVT). Seoul: Seoul Community Rehabilitation Center.

Lee, E. J., Park, J. H., Shin, M. J., \& Sim, H. S. (2009). Comparing the clinical judgments of stuttering specialists to stuttering severity rated by the Paradise-Fluency Assessment (P-FA). Korean Journal of Communication \& 
Disorders, 14, 200-211.

Lee, E. J., \& Sim, H. S. (2003). Phonological memory in the nonword repetition of children: a comparison of functional phonologically disordered and normal children. Korean Journal of Communication \& Disorders, 8 , 127-145.

Lee, S. B., \& Sim, H. S. (2015). A longitudinal study of utterance length in morphemes as a predictor of treatment outcome in early childhood stuttering. Communication Sciences \& Disorders, 20, 189-201.

Lee, Y., Yim, D., \& Sim, H. (2012). Phonological processing skills and its relevance to receptive vocabulary development in children with early cochlear implantation. International Journal of Pediatric Otorhinolaryngology, 76, 1755-1760.

Lim, J., \& Hwang, M. (2009). The characteristics of mazes in story retelling by children with attention deficit hyperactivity disorder. Korean Journal of Communication \& Disorders, 14, 96-108.

Loban, W. (1976). Language development: kindergarten through grade twelve. Urbana, IL: National Council of Teachers of English.

Logan, K. J., \& Conture, E. G. (1995). Length, grammatical complexity, and rate differences in stuttered and fluent conversational utterances of children who stutter. Journal of Fluency Disorders, 20, 35-61.

Masterson, J. J., \& Kamhi, A. G. (1992). Linguistic trade-off in school-age children with and without language disorders. Journal of Speech and Hearing Disorders, 35, 1064-1075.

Melnick, K. S., \& Conture, E. G. (2000). Relationship of length and grammatical complexity to the systematic and nonsystematic speech errors and stuttering of children who stutter. Journal of Fluency Disorders, 25, 21-45.

Miles, S., \& Ratner, N. B. (2001). Parental language input to children at stuttering onset. Journal of Speech, Language, and Hearing Research, 44, 11161130.

Montgomery, J. W. (2003). Working memory and comprehension in children with specific language impairment: what we know so far. Journal of Communication Disorders, 36, 221-231.

Moon, S. B., \& Byun, C. J. (2003). Korean Kaufman assessment battery for children $(K-A B C)$. Seoul: Hakjisa.

Navarro-Ruiz, M. I., \& Rallo-Fabra, L. (2001). Characteristics of mazes produced by SLI children. Clinical Linguistics and Phonetics, 15, 63-66.

Nippold, M. A. (2002). Stuttering and phonology: is there an interaction? American Journal of Speech-Language Pathology, 11, 99-110.

Oomen, C. C., \& Postma, A. (2001). Effects of divided attention on the production of filled pauses and repetitions. Journal of Speech, Language, and
Hearing Research, 44, 997-1004.

Pae, S., Rice, M. L., \& Oetting, J. B. (1999). A study on Korean children's word acquisition by QUIL (quick incidental learning) I: a crosslinguistic perspective. In Professor Lee Seung-Hwan's Retirement Commemorative Book. Seoul: Korean Cultural History.

Postma, A. (1991). Stuttering and self-correction: on the role of linguistic repair processes in disfluencies of normal speakers and stutterers. Nijmegen: Nijmeegs instituut voor cognitieonderzoek en informatietechnologie.

Postma, A., \& Kolk, H. (1992). Error monitoring in people who stutter evidence against auditory feedback defect theories. Journal of Speech, Language, and Hearing Research, 35, 1024-1032.

Postma, A., \& Kolk, H. (1993). The covert repair hypothesis: prearticulatory repair processes in normal and stuttered disfluencies. Journal of Speech, Language, and Hearing Research, 36, 472-487.

Postma, A., Kolk, H., \& Povel, D. J. (1990). On the relation among speech errors, disfluencies, and self-repairs. Language and Speech, 33, 19-29.

Ratner, N. B., \& Sih, C. C. (1987). Effects of gradual increases in sentence length and complexity on children's dysfluency. Journal of Speech and Hearing Disorders, 52, 278-287.

Redmond, S. M. (2004). Conversational profiles of children with ADHD, SLI and typical development. Clinical Linguistics \& Phonetics, 18, 107-125.

Richels, C., Buhr, A., Conture, E., \& Ntourou, K. (2010). Utterance complexity and stuttering on function words in preschool-age children who stutter. Journal of Fluency Disorders, 35, 314-331.

Ryan, B. P. (1992). Articulation, language, rate, and fluency characteristics of stuttering and nonstuttering preschool children. Journal of Speech, Language, and Hearing Research, 35, 333-342.

Shapiro, D. A. (1999). Stuttering intervention: a collaborative journey to fluency freedom. Austin, TX: Pro-Ed.

Sim, H. S., Shin, M. J., \& Lee, E. J. (2010). Paradise-Fluency Assessment II. Seoul: Paradise Welfare Foundation.

Starkweather, C. W. (1987). Fluency and stuttering. Englewood Cliffs, NJ: Prentice-Hall.

Starkweather, C. W., \& Gottwald, S. R. (1990). The demands and capacities model II: clinical applications. Journal of Fluency Disorders, 15, 143-157.

Stoel-Gammon, C., \& Dunn, C. (1985). Normal and disordered phonology in children. Austin, TX: Pro-Ed.

Sung, S. J., \& Sim, H. S. (2002). Relationships among utterance length, syntactic complexity, and disfluencies in preschool children who stutter. Korean Journal of Communication \& Disorders, 7, 102-129. 
Yoonhee Yang, et al. • Linguistic Disfluency Induced by Nonword and Sentence Repetition Task

Westby, C. E. (1979). Language performance of stuttering and nonstuttering children. Journal of Communication Disorders, 12, 133-145.

Yairi, E., \& Ambrose, N. G. (2005). Early childhood stuttering for clinicians by clinicians. Austin, TX: Pro Ed.

Yairi, E., Ambrose, N. G., Paden, E. P., \& Throneburg, R. N. (1996). Predic- tive factors of persistence and recovery: pathways of childhood stuttering. Journal of Communication Disorders, 29, 51-77.

Yaruss, J. S (1999). Utterance length, syntactic complexity, and childhood stuttering. Journal of Speech and Hearing Research, 42, 329-344. 
Appendix 1. Nonword repetition (NWR) task

\begin{tabular}{|c|l|}
\hline 문황 & \multicolumn{1}{|c|}{ 비단어 } \\
\hline \hline 연습(1) & 따무 \\
\hline 연습(2) & 뿌커디 \\
\hline
\end{tabular}

\begin{tabular}{|l|l|}
\hline 1 & 누베 \\
\hline 2 & 마뚜 \\
\hline 3 & 조나 \\
\hline 4 & 퍼틱 \\
\hline 5 & 버줍디 \\
\hline 6 & 까다굳 \\
\hline 7 & 모단기 \\
\hline 8 & 니아토 \\
\hline 9 & 토보가인 \\
\hline 10 & 머구낭볼 \\
\hline 11 & 푸가태지 \\
\hline 12 & 드반거노 \\
\hline 13 & 조매누버리 \\
\hline 14 & 레빌애티머 \\
\hline 15 & 누빈재구밈 \\
\hline 16 & 바즘다거니 \\
\hline 17 & 무지다바리노 \\
\hline 18 & 로밉띠르저니 \\
\hline 19 & 보마데낭까두 \\
\hline 20 & 미기듣아캐바 \\
\hline \hline
\end{tabular}

Appendix 2. Sentence repetition (SR) task

\begin{tabular}{|c|l|}
\hline 문항 & \multicolumn{1}{|c|}{ 검사문장 } \\
\hline \hline 연습(1) & 아기가 울어요 \\
\hline 연습(2) & 머리를 빗어요 \\
\hline
\end{tabular}

\begin{tabular}{|c|c|}
\hline 1 & 그림을 연필로 그려요. \\
\hline 2 & 색좋이를 풀로 붙여요. \\
\hline 3 & 머리를 샴푸로 감아요. \\
\hline 4 & 돟생이 그림책블 봐요. \\
\hline 5 & 엄마가 지마를 입어요. \\
\hline 6 & 아봐가 신문을 읽어요. \\
\hline 7 & 아가가 집에서 놀아요 \\
\hline 8 & 친구가 자에서 내려요. \\
\hline 9 & 엄마가 시장에서 와요. \\
\hline 10 & 돟생이 작은 칫솔로 이빨을 닦아요. \\
\hline 11 & 엄마가 커다란 비누로 빨래를 해요. \\
\hline 12 & 친구가 작은 가위로 종이를 잘라요. \\
\hline 13 & 아봐가 동생한테 맛있는 빵을 줘요. \\
\hline 14 & 아봐가 아가한테 작은 공을 던져요. \\
\hline 15 & 아빠가 아가한테 예뽄 옷을 사줘요. \\
\hline 16 & 친구가 밖에서 그네를 재밌게 타요. \\
\hline 17 & 엄마가 부얼에서 밥을 맛있게 해요. \\
\hline 18 & 엄마가 시장에서 사과를 조금 사요. \\
\hline 19 & 친구가 목욕을 하고 머리를 감아요. \\
\hline 20 & 돟생이 바지를 입고 양말을 신어요. \\
\hline 21 & 엄마가 정소를 하고 걸레를 빨아요. \\
\hline 22 & 아가가 아파서 주사를 많이 맞아요. \\
\hline 23 & 친구가 배고파서 밥을 빨리 억어요. \\
\hline 24 & 아뽜가 힘들어서 하품을 크게 해요. \\
\hline 25 & 아가가 안자면 엄마가 우유를 줘요. \\
\hline 26 & 동생이 추우면 엄마가 이불을 줘요. \\
\hline 27 & 돟생이 아프면 아뽜가 약을 사와요. \\
\hline 28 & 친구는 수영을 하는 것을 좋아해요. \\
\hline 29 & 친구는 노래를 하는 것을 섫어해요. \\
\hline 30 & 아가는 그림을 그리는 것을 못해요. \\
\hline 31 & 친구가 잠을 자는 강아지를 깨워요. \\
\hline 32 & 아뽜가 청소를 하는 엄마를 불러요. \\
\hline 33 & 엄마가 머리를 발리 감으라고 해요. \\
\hline 34 & 아뽜가 방을 깨못이 닦으라고 해요. \\
\hline 35 & 아뽜가 창문블 세게 닫으라고 해요. \\
\hline
\end{tabular}

Appendix 3. Standard analysis of disfluency type

\begin{tabular}{|c|c|c|c|}
\hline \multirow{2}{*}{ Disfluency type } & \multirow{2}{*}{ Definition } & \multicolumn{2}{|c|}{ Example } \\
\hline & & Nonword repetition & Sentence repetition \\
\hline \multirow[t]{2}{*}{ R1 } & 다음절낱말, 어절, 구 등의 반복 & 미기돋아캐바 & 아가가 아파서 주사를 많이 맞아요. \\
\hline & & -> 미기돋아캐바, 미기돋아캐바 & ->아가가, 아가가 아파서 주사를 많이 맞아요. \\
\hline \multirow[t]{2}{*}{ R2 } & 음소, 음절부분, 음절, 낱말부분, 일음절낱말의 & 미기돋아캐바 & 아빠가 힘들어서 하품을 크게 해요. \\
\hline & 반복 & $\rightarrow$ 미, 미기, 미기돋아캐바 & ->아빠가 힘들어서 하, 하품을 크게 해요. \\
\hline \multirow[t]{2}{*}{ Rev } & 이미 산출한 말의 발음, 낱말, 통사구조 등을 바꾸 & 미기돋아캐바 & 동생이 추우면 엄마가 이불을 줘요. \\
\hline & 어 다시 말하는 경우 & -> 디기, 아니야 미기돋아캐바 & ->동생이 추우면 할미 아니 엄마가 이불을 줘요 \\
\hline \multirow[t]{2}{*}{ I } & 의미전달내용과 관계없는 '음, 어, 그' 등의 무의 & 미기돋아캐바 & 동생이 아프면 아빠가 약을 사와요. \\
\hline & 미 음절을 삽입하는 간투사가 출현하는 경우 & $\rightarrow$ 미기 어 뭐지 돋 아 캐바 & ->동생이 어 아프면 아빠가 약을 어 사와요. \\
\hline \multirow[t]{2}{*}{ DP } & 연장, 막힘, 깨진 낱말이 출현하는 경우 & 미기돋아캐바 & 아빠가 창문을 세게 닫으라고 해요. \\
\hline & & -> 미기도옫-아윽--캐바 & ->아빠가 창문을 세게 닫-아요. \\
\hline
\end{tabular}

R1=repetition 1; R2=repetition2; Rev=revision; l=interjection; DP=dishythmic phonation. 


\title{
국문초록
}

\author{
학령 전 어휘발달지연 및 또래 일반 아동의 언어학적 비유창성 특성과 표현어휘력의 관계 \\ 양윤희 · 심현섭 · 임동선 \\ 이화여자대학교 대학원 언어병리학과
}

배경 및 목적: 본 연구는 학령 전 어휘발달지연 및 또래 일반 아동이 음운기억 부담이 부과되는 비단어 및 문장 따라말하기 과제 수행 시 나타나는 언어학적 비유창성 양상이 집단에 따라 차이가 있는지, 언어학적 비유창성 특성은 수용 및 표현 어휘력과 유의한 상관이 있는지, 그리고 각 집단의 언어학적 비유창성 특성이 수용 및 표현어휘력을 설명할 수 있는지 알아보고자 하였다. 방법: 만 5-6세의 어 휘발달지연 아동 17 명, 생활연령을 일치시킨 일반 아동 18 명, 총 35 명을 대상으로 비단어 및 문장 따라말하기 과제의 수행을 시행하였 으며, 산출된 발화의 비유창성 특성을 분석하였다. 자료의 통계적 분석을 위해 반복측정분산분석, Pearson의 적률상관계수, 그리고 단 계적 중다회귀분석을 실시하였다. 결과: 비단어 따라말하기 과제에서 언어학적 비유창성 빈도는 집단 간 유의한 차이가 없었으나, 문장 따라말하기 과제에서는 집단 간 유의한 차이가 있었다. 일반 아동 집단에서 수용 및 표현 어휘력과 언어학적 비유창성 특성 사이에 유 의한 상관은 나타나지 않았으나, 어휘발달지연 아동 집단에서는 문장 따라말하기 과제에서 발생한 반복2 (음소 및 음절반복) 비유창성 유형이 표현 어휘력과 유의한 상관관계가 있는 것으로 나타났다. 특히, 어휘발달지연 집단에서 반복 2 가 표현어휘력을 약 $47 \%$ 유의하게 예측하는 것으로 나타났다. 논의 및 결론: 본 연구의 결과는 음운학적(언어적) 부담이 증가한 경우 학령전기 어휘발달지연 아동들의 언 어 및 어휘적 어려움이 발화산출에 부정적 영향을 미쳐 비유창성 빈도가 증가할 수 있음을 시사한다. 그러므로 학령전기 어휘발달지연 아동들은 말하기 상황에서 목표 자극의 길이 및 복잡성의 부담을 스스로 최대한 줄여 산출하는 훈련의 필요성이 고려되어야한다.

핵심어: 음운기억 부담, 비단어 따라말하기, 문장 따라말하기, 언어학적 비유창성, 학령 전 어휘발달지연

\section{참고문헌}

김영태, 홍경훈, 김경희, 장혜성, 이주연(2009). 수용·표현어휘력검사(REVT). 서울: 서울장애인종합복지관.

문수백, 변창진(2003). K-ABC 교육·심리측정도구(Korean-Kaufman assessment battery for children). 서울: 학지사.

배소영, M. L. Rice, J. B. Oetting (1999). QUIL (quick incidental learning)에 의한 한국 아동의 낱말습득 연구 I: a crosslinguistic perspective. 이승환 교수 정년기념 논문집. 서울: 한국문화사.

성수진, 심현섭(2002). 학령전기 유창성장애아동의 발화길이 및 통사적 복잡성과 비유창성의 관계 연구. 언어청각장애연구, 7, 102-129.

심현섭, 신문자, 이은주(2010). 파라다이스-유창성 검사II. 서울: 파라다이스 복지재단.

안지숙, 김영태(2000). 단순언어장애 아동과 정상아동의 구문적 난이도에 따른 문장 따라말하기: 수행력 및 명료도 비교. 음성과학, 7, 249-262.

이수복, 심현섭(2015). 초기 말더듬아동의 치료후 말더듬회복 예측요인에 관한 종단연구: 발화길이를 중심으로. 언어청각장애연구, 20, 189-201.

이은주, 박정현, 신문자, 심현섭(2009). 유창성장애 전문가들의 임상적 판단과 파라다이스-유창성 검사 결과 간의 비교 연구. 언어청각장애연구, 14, 200-211.

이은주, 심현섭(2003). 무의미 음절 따라말하기를 통한 단순조음음운장애 아동과 정상아동의 음운기억 수행능력 비교연구. 언어청각장애연구, 8, 127-145.

임종아, 황민아(2009). 이야기 다시말하기에서 나타난 아동의 mazes 특성. 언어청각장애연구, 14, 96-108.

정동빈(1994). 언어발달지도. 서울: 한국문화사.

정은희, 이규식(1999). 일본어 아동과 한국어 아동의 문장이해전략에 관한 연구-어순과 조사에 의한 문이해를 중심으로. 난청과 언어치료연구, 22, 77-94. 